\title{
Reactivity of Tungsten-aryloxides with Hydrosilane Cocatalysts in Olefin Metathesis
}

\author{
Ione M. Baibich ${ }^{a *}$ and Carla Kern ${ }^{b}$ \\ ${ }^{a}$ Instituto de Química, Universidade Federal do Rio Grande do Sul, CP 15003, 91501-970 Porto Alegre - RS, Brazil \\ ${ }^{b}$ Instituto de Química, Universidade Estadual Paulista, CP 355, 14800-900, Araraquara - SP, Brazil and \\ Centro Universitário UNIVATES, Rua Avelino Talini, 171, 95900-000, Lageado - RS, Brazil
}

As reatividades dos sistemas $\left[\mathrm{WCl}_{4}(\mathrm{OAr})_{2}\right]\left(\mathrm{OAr}=\mathrm{O}-2,6-\mathrm{C}_{3} \mathrm{H}_{3} \mathrm{Cl}_{2}, \mathrm{O}-2,6-\mathrm{C}_{6} \mathrm{H}_{3} \mathrm{~F}_{2}\right.$ e O$\mathrm{C}_{6} \mathrm{H}_{3} \mathrm{Me}_{2}$ ), juntamente com os compostos de silício $\mathrm{Ph}_{2} \mathrm{SiH}_{2}$ e polimetilidrosiloxano (PMHS), foram estudadas em reações de metátese. As olefinas usadas foram 10-undecenoato de metila e 1hexeno. Os resultados mostraram que os sistemas $\left[\mathrm{WCl}_{4}(\mathrm{OAr})_{2}\right]$-composto de silício são ativos e seletivos quando os ligantes arilóxidos possuem grupos eletronegativos em suas estruturas. $\mathrm{O}$ composto de silício PMHS apresentou os melhores resultados, mesmo com o composto [ $\mathrm{WCl}_{4}(\mathrm{O}-$ 2,6- $\left.\mathrm{C}_{6} \mathrm{H}_{3} \mathrm{Me}_{2}\right)_{2}$ ], que não possui substituintes eletronegativos. Por ser não-tóxico, não-volátil, barato e de fácil manuseio, PMHS é uma boa alternativa como cocatalisador em reações de metátese.

\begin{abstract}
The reactivity of the $\left[\mathrm{WCl}_{4}(\mathrm{OAr})_{2}\right]\left(\mathrm{OAr}=\mathrm{O}-2,6-\mathrm{C}_{3} \mathrm{H}_{3} \mathrm{Cl}, \mathrm{O}-2,6-\mathrm{C}_{6} \mathrm{H}_{3} \mathrm{~F}_{2}\right.$ and $\left.\mathrm{O}-\mathrm{C}_{6} \mathrm{H}_{3} \mathrm{Me}_{2}\right)$ systems, plus the silicon compounds $\mathrm{Ph}_{2} \mathrm{SiH}_{2}$ and polymethylhydrosiloxane (PMHS), were studied in metathesis reactions. The olefins used were methyl-10-undecenoate and 1-hexene. The results showed that the $\left[\mathrm{WCl}_{4}(\mathrm{OAr})_{2}\right]$-silicon compound systems are active and selective when the aryloxide ligand contain electronegative groups. The silicon compound PMHS proved to be the best cocatalyst for metathesis, even with the $\left[\mathrm{WCl}_{4}\left(\mathrm{O}-2,6-\mathrm{C}_{6} \mathrm{H}_{3} \mathrm{Me}_{2}\right)_{2}\right]$ compound, which has no electronegative substituents. Because it is non-toxic, non-volatile, easy to handle and cheap, PMHS is a good alternative cocatalyst in metathesis reactions.
\end{abstract}

Keywords: tungsten catalysts, hydrosilane cocatalysts, olefin metathesis

\section{Introduction}

Olefin metathesis reactions have been used in recent years as a well-established synthetic method in both industrial and laboratorial applications. ${ }^{1-3}$ The reaction consists of an alkene double bond cleavage, followed by a statistic redistribution of alkylidene fragments.

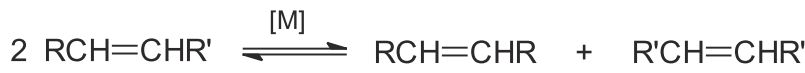

This reaction allows for new olefins to be synthesized and used as raw materials in polymers, perfumes, drugs and agrochemical industrial products, also serving as the starting point for more complex organic molecules. Catalytic systems are based mainly on the metals W, Mo, $\mathrm{Re}$ and $\mathrm{Ru}$. The metal-alkylidenes synthesized by Schrock, ${ }^{4}$

\footnotetext{
* e-mail: ione@iq.ufrgs.br
}

$\left[\mathrm{Mo}(\mathrm{CHR})(\mathrm{NAr})\left(\mathrm{OR}_{\mathrm{f}}\right)_{2}\right]$, Grubbs, $\left[\mathrm{Ru}(\mathrm{CHR})\left(\mathrm{PCy}_{3}\right)_{2} \mathrm{Cl}_{2}\right],{ }^{5}$ Herrmann $^{6}$ and Dixneuf ${ }^{7}$ are particularly interesting catalysts for olefin metathesis. When a catalyst is not a metal-alkylidene, a cocatalyst is added to generate a metalcarbene, known as the active species for metathesis. The homogeneous system $\left[\mathrm{WCl}_{6}\right] / \mathrm{SnR}_{4}$ is extensively studied in the literature and is appropriate for non-functionalized and fuctionalized ${ }^{8}$ olefins.

Tungsten-aryloxides $\left[\mathrm{WCl}_{4}(\mathrm{OAr})_{2}\right]$ are useful because they can be easily synthesized from $\left[\mathrm{WCl}_{6}\right]$ and its corresponding phenol and offer good handling stability. ${ }^{9}$ Moreover, these compounds are very versatile, because their activity and stereoselectivity can be modified, by changing their ring substituents. Thus, electronegative groups increase the reduction potential of tungsten atoms, enhancing the catalytic activity of these compounds in metathesis. ${ }^{10,11}$ Furthermore, stereoselectivity can be achieved by placing bulky groups in 2,6 positions of the ring.

In previous studies ${ }^{12,13}$ we investigated the catalytic activity of a new system based on $\left[\mathrm{WCl}_{6}\right]$ plus PMHS 
(polymethylhydrosiloxane) in functionalized olefins. The new system displayed a behavior similar to others reported in the literature. ${ }^{1}$ Furthermore, a study of different hydrosilane compounds and promoters, such as phenols, were used in the metathesis of 1 -hexene. ${ }^{11} \mathrm{We}$ also reported on olefin metathesis in the presence of [ $\mathrm{WCl}_{4}(\mathrm{OAr})_{2}$, which showed good selectivity without the need for promoters.

In order to further investigate these systems, we have studied the catalytic activity of $\left[\mathrm{WCl}_{4}(\mathrm{OAr})_{2}\right](\mathrm{OAr}=\mathrm{O}-$ 2,6- $\mathrm{C}_{6} \mathrm{H}_{3} \mathrm{Cl}_{2}, \mathrm{O}-2,6-\mathrm{C}_{6} \mathrm{H}_{3} \mathrm{~F}_{2}$ and $\mathrm{O}-2,6-\mathrm{C}_{6} \mathrm{H}_{3} \mathrm{Me}_{2}$ ) in the 1hexene reaction. By changing the electronic effects of the ring, we hoped to see differences in the activity of these compounds. The compounds $\mathrm{Ph}_{2} \mathrm{SiH}_{2}$ and PMHS were used as cocatalysts while $\mathrm{SnMe}_{4}$ served for comparison purposes. Furthermore, we extended the use of these compounds to methyl-10-undecenoate metathesis. Although the Schrock and Grubbs metal alkylidenes are still considered the "pillars of contemporary olefin metathesis", ${ }^{14}$ research on simpler systems based on $\left[\mathrm{WCl}_{6}\right]$ or its derivatives is worthwhile owing to the less expensive nature of the latter compounds, which allows for their large scale application as, for instance, in vegetable oils metathesis. ${ }^{15}$ Therefore, the study of these systems applied to a functionalized olefin is fully justified.

\section{Experimental}

\section{Reagents and solvents}

$\left[\mathrm{WCl}_{6}\right.$ ], $\mathrm{Ph}_{2} \mathrm{SiH}_{2}, \mathrm{PMHS}, 2,6-\mathrm{Cl}_{2} \mathrm{C}_{6} \mathrm{H}_{3} \mathrm{OH}, 2,6-$ $\mathrm{F}_{2} \mathrm{C}_{6} \mathrm{H}_{3} \mathrm{OH}, 2,6-\mathrm{Me}_{2} \mathrm{C}_{6} \mathrm{H}_{3} \mathrm{OH}$, 1-hexene, methyl-10undecenoate and standard olefins $\left(\mathrm{C}_{10}\right.$ and $\left.\mathrm{C}_{12}\right)$ were purchased from Aldrich Chemical Company. PMHS is a low viscosity, non-toxic, easy to handle liquid whose molecular formula is $\left(\mathrm{CH}_{3}\right)_{3} \mathrm{Si}-\mathrm{O}-\left[\mathrm{Si}(\mathrm{H})\left(\mathrm{CH}_{3}\right)-\mathrm{O}\right]_{\mathrm{n}}{ }^{-}$ $\mathrm{Si}\left(\mathrm{CH}_{3}\right)_{3}, \mathrm{n} \approx 35$. Chlorobenzene (Merck), and 1-hexene were deoxygenated and dried using standard techniques. Methyl 10-undecenoate (ATO Chemie) was purified by washing with $1 \mathrm{~mol} \mathrm{~L}^{-1} \mathrm{NaOH}$ and water to remove acidic impurities, dried with $\mathrm{MgSO}_{4}$, vacuum-distilled, and stored on $4 \AA$ molecular sieves. All the experiments were performed under inert atmosphere.

The compounds $\left[\mathrm{WCl}_{4}\left(\mathrm{O}-2,6-\mathrm{C}_{6} \mathrm{H}_{3} \mathrm{Cl}_{2}\right)_{2}\right],\left[\mathrm{WCl}_{4}(\mathrm{O}-2,6-\right.$ $\left.\left.\mathrm{C}_{6} \mathrm{H}_{3} \mathrm{~F}_{2}\right)_{2}\right]$, and $\left[\mathrm{WCl}_{4}\left(\mathrm{O}-2,6-\mathrm{C}_{6} \mathrm{H}_{3} \mathrm{Me}_{2}\right)_{2}\right]$ were synthesized according to procedures reported in the literature. ${ }^{16}$

\section{1-Hexene metathesis}

The reactions were performed in a $50 \mathrm{~mL}$ flask connected to a condenser. The reactants were introduced into the flask with degassed solvent in the following order: 1-hexene, $[\mathrm{W}]\left(10^{-4}\right.$ mole $)$ and cocatalyst in a molar ratio of $100: 1: 4$, respectively. The reactions were carried out at $323 \mathrm{~K}$ for $4 \mathrm{~h}$ and interrupted by admitting air, followed by filtration through a silica/celite preparative column. Cyclohexane was added to the reaction mixture as an internal standard for GC analysis. The reactions were performed at least three times to ensure reproducibility.

The products were analyzed using an HP-5890 GC instrument equipped with a methyl-silicone megabore column (HP-1) and FID detector. The internal standard method (with cyclohexane) was used to calculate the mass percentage of 1-hexene and products. Peak identification was performed using GC/MS and spiking on authentic samples.

The mass spectra were measured with an HP 5988A mass spectrometer coupled to an HP 5890 GC. The mass spectra signals were $(\mathrm{EI}, 70 \mathrm{eV}) \mathrm{m} / \mathrm{z} 140(\mathrm{M}), 70\left(\mathrm{M}-\mathrm{C}_{5} \mathrm{H}_{10}\right)$, $69\left(\mathrm{M}-\mathrm{C}_{5} \mathrm{H}_{11}\right), 55\left(\mathrm{M}-\mathrm{C}_{6} \mathrm{H}_{13}\right)$, for decene and $97\left(\mathrm{M}-\mathrm{C}_{6} \mathrm{H}_{11}\right)$, $70\left(\mathrm{M}-\mathrm{C}_{7} \mathrm{H}_{14}\right), 69\left(\mathrm{M}-\mathrm{C}_{7} \mathrm{H}_{15}\right), 55\left(\mathrm{M}-\mathrm{C}_{8} \mathrm{H}_{17}\right)$, for dodecene.

The results are presented as yields in 5-decene and byproducts that are formed mainly by dimerization and by traces of isomerization and co-metathesis between the different isomers formed, which are defined as:

$$
\text { Yield in } \mathrm{C}_{10}=\frac{\mathrm{m} \text { (5-decene) }}{\mathrm{m}_{\text {unreacted } 1 \text {-hexene }}+\Sigma \mathrm{m}_{\text {products }}}
$$

Yield in $\mathrm{C}_{\text {by-products }}=\frac{\mathrm{m} \text { (by-products) }}{\mathrm{m}_{\text {unreacted 1-hexene }}+\Sigma \mathrm{m}_{\text {products }}}$

The term " $\Sigma \mathrm{m}_{\text {products }}$ " includes the ethylene mass, taking into account that 1 mole of ethylene is released by each mole of 5-decene that is formed.

The total conversion and selectivities can be calculated by:

Total Conversion $=$ Yield in $\mathrm{C}_{10}+$ Yield in $\mathrm{C}_{\text {by-products }}$
Selectivity in $\mathrm{C}_{10}=\frac{\text { Yield in } \mathrm{C}_{10}}{\text { Total Conversion }}$

Methyl-10-undecenoate metathesis reaction

In a typical reaction, the tungsten compound was added to a flask containing methyl-10-undecenoate followed by the addition of cocatalyst according to a molar ratio of 25:1:4. The reactions were carried out at $348 \mathrm{~K}$ for $4 \mathrm{~h}$ and interrupted by allowing air into the system, followed by filtration through a silica/celite preparative column and analysis by ${ }^{1} \mathrm{H}$ NMR spectroscopy. 
The NMR spectra were obtained using a VARIAN CXR $200 \mathrm{MHz}$ spectrometer and $\mathrm{CDCl}_{3}$ as solvent. The conversion factors $(\mathrm{C})$ were estimated from the integration of the olefinic proton signals by the equation $\mathrm{C}=2 \mathrm{D} /\left(\mathrm{E}_{2}+\right.$ $2 \mathrm{D})$, where $\mathrm{D}=$ integration of the diester olefinic proton signals and $\mathrm{E}_{2}=$ integration of the two terminal ester olefinic proton signals. Tests with calibrated solutions ensured a maximum margin of error of $4 \% .^{12}$

\section{Results and Discussion}

Table 1 presents the yields obtained in the metathesis of 1-hexene at $50^{\circ} \mathrm{C}$, using tungsten-aryloxides as catalysts and silicon and tin compound cocatalysts.

The reaction is satisfactory at this temperature, using silicon compounds, but gives poor yields when $\mathrm{SnMe}_{4}$ is the co-catalyst. This result is surprising since $\mathrm{SnMe}_{4}$ is a classical cocatalyst in olefin metathesis. ${ }^{8}$ Furthermore, no product is formed when the tungsten-aryloxide is $\mathrm{WCCl}_{4}(\mathrm{O}-$ $\left.\mathrm{C}_{6} \mathrm{H}_{3} \mathrm{Me}_{2}\right)_{2}$ ], except when the cocatalyst is PMHS. It has been previously reported ${ }^{17}$ that $\left[\mathrm{WCl}_{4}\left(\mathrm{O}-\mathrm{C}_{6} \mathrm{H}_{3} \mathrm{Me}_{2}\right)_{2}\right]$ is the only tungsten-aryloxide that presents a negative reduction potential, and is the most difficult complex to be reduced. On the other hand, PMHS is known to be a reducer, ${ }^{18}$ hence it increases the activity of the tungsten compound.

The cocatalysts most frequently reported in the literature for $\left[\mathrm{WCl}_{4}(\mathrm{OAr})_{2}\right]$ are aluminumalkyl and leadalkyl compounds. The literature contains few examples ${ }^{11,19}$ of $\left[\mathrm{WCl}_{4}(\mathrm{OAr})_{2}\right]-\mathrm{SnMe}_{4}$, whose reactions were performed at $85{ }^{\circ} \mathrm{C}$. Vosloo et al. ${ }^{19}$ reported that activity increased drastically from 50 to $65{ }^{\circ} \mathrm{C}$ in metathesis with the $\left[\mathrm{WCl}_{4}(\mathrm{OAr})_{2}\right]-\mathrm{SnBu}_{4}$ system, although they found no activity at $50^{\circ} \mathrm{C}$ for that system. Therefore, we repeated the reaction for $\left[\mathrm{WCl}_{4}\left(\mathrm{O}-\mathrm{C}_{6} \mathrm{H}_{3} \mathrm{Cl}_{2}\right)_{2}\right]$ at $65^{\circ} \mathrm{C}$ (Table 2). As can be observed, $\mathrm{SnMe}_{4}$ proved to be an effective cocatalyst at this temperature, contrary to the results shown in Table 1 , when the temperature was $50{ }^{\circ} \mathrm{C}$.

Figure 1 illustrates the yield $v s$. time curves for 1-hexene metathesis using $\left[\mathrm{WCl}_{4}\left(\mathrm{O}-\mathrm{C}_{6} \mathrm{H}_{3} \mathrm{Cl}_{2}\right)_{2}\right]$-cocatalyst. As can be seen, $\mathrm{PMHS}$ and $\mathrm{SnMe}_{4}$ initially display a similar behavior
Table 2. Yields of the products of 1-hexene metathesis with the catalytic system $\left[\mathrm{WCl}_{4}\left(\mathrm{O}-\mathrm{C}_{6} \mathrm{H}_{3} \mathrm{Cl}_{2}\right)_{2}\right]$-cocatalyst and chlorobenzene as solvent. Reaction time: $5 \mathrm{~h}$. Temperature: $338 \mathrm{~K}$.

\begin{tabular}{lll}
\hline Cocatalyst & Yield in 5-decene (\%) & By-products (\%)* \\
\hline $\mathbf{P h}_{2} \mathbf{S i H}_{2}$ & $64 \pm 6$ & $28 \pm 4$ \\
$\mathbf{P M H S}_{\mathbf{S n M e}_{4}}$ & $86 \pm 4$ & $14 \pm 3$ \\
\hline
\end{tabular}

*The by-products contain mainly dodecene, a product of hexene dimerization.

The reactions were performed at least three times.

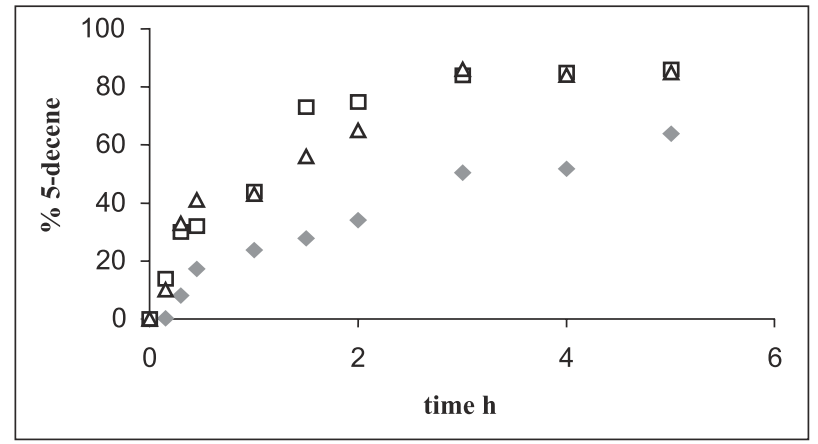

Figure 1. Yield of 5-decene versus time, obtained for the catalytic systems $\bullet\left[\mathrm{WCl}_{4}\left(\mathrm{O}-\mathrm{C}_{6} \mathrm{H}_{3} \mathrm{Cl}_{2}\right)_{2}\right]-\mathrm{Ph}_{2} \mathrm{SiH}_{2}, \square\left[\mathrm{WCl}_{4}\left(\mathrm{O}-\mathrm{C}_{6} \mathrm{H}_{3} \mathrm{Cl}_{2}\right)_{2}\right]-\mathrm{PMHS}$ and $\Delta\left[\mathrm{WCl}_{4}\left(\mathrm{O}-\mathrm{C}_{6} \mathrm{H}_{3} \mathrm{Cl}_{2}\right)_{2}\right]-\mathrm{SnMe}_{4}$.

$\left(100-120 \mathrm{~h}^{-1}\right)$ and the same final conversion. The system with $\mathrm{Ph}_{2} \mathrm{SiH}_{2}$ presents lower initial activity $\left(50 \mathrm{~h}^{-1}\right)$ and lower final conversion, and is also the least selective, as shown by the results in Table 2 . The activities and selectivities obtained with the $\left[\mathrm{WCl}_{4}(\mathrm{OAr})_{2}\right]$-cocatalyst are comparable to those obtained previously ${ }^{13}$ with $\left[\mathrm{WCl}_{6}\right]$ cocatalyst-phenol, when phenol was added as a reaction promoter probably forming tungsten aryloxides in situ. However, the absence of phenol in this system leads primarily to dimerization and not to metathesis.

Table 3 shows the results of the metathesis reaction of methyl-10-undecenoate using $\left[\mathrm{WCl}_{4}\left(\mathrm{O}-\mathrm{C}_{6} \mathrm{H}_{3} \mathrm{Cl}_{2}\right)_{2}\right]$ and [WCl $]$ from a previous study ${ }^{12}$, for comparison. The results are as good as the earlier ones, with the added advantage that the use of $\left[\mathrm{WCl}_{4}\left(\mathrm{O}-\mathrm{C}_{6} \mathrm{H}_{3} \mathrm{Cl}_{2}\right)_{2}\right]$ requires no drastically

Table 1. Yields of the products of 1-hexene metathesis with the catalytic system $\left[\mathrm{WCl}_{4}(\mathrm{OAr})_{2}\right]$-cocatalyst and chlorobenzene as solvent. Reaction time: $4 \mathrm{~h}$. Temperature: $323 \mathrm{~K}$.

\begin{tabular}{|c|c|c|c|c|c|c|}
\hline \multirow[b]{2}{*}{ catalyst } & \multicolumn{5}{|c|}{ cocatalyst } & \multirow[b]{2}{*}{$\begin{array}{l}\text { byproducts* } \\
(\%)\end{array}$} \\
\hline & $\begin{array}{l}\mathrm{Ph}_{2} \mathrm{SiH}_{2} \\
\text { 5-decene } \\
(\%)\end{array}$ & $\begin{array}{l}\text { by-products } \\
(\%)\end{array}$ & $\begin{array}{l}\text { PMHS } \\
\text { 5-decene } \\
(\%)\end{array}$ & $\begin{array}{l}\text { by-products } \\
(\%)\end{array}$ & $\begin{array}{l}\mathrm{SnMe}_{4} \\
\text { 5-decene } \\
(\%)\end{array}$ & \\
\hline$\left[\mathrm{WCl}_{4}\left(\mathrm{O}-\mathrm{C}_{6} \mathrm{H}_{3} \mathrm{Cl}_{2}\right)_{2}\right]$ & $81 \pm 5$ & $9 \pm 2$ & $56 \pm 4$ & $24 \pm 4$ & $10 \pm 2$ & $71 \pm 3$ \\
\hline$\left[\mathrm{WCl}_{4}\left(\mathrm{O}-\mathrm{C}_{6} \mathrm{H}_{3} \mathrm{~F}_{2}\right)_{2}\right]$ & $85 \pm 8$ & $5 \pm 3$ & $77 \pm 5$ & $3 \pm 2$ & $4 \pm 2$ & $68 \pm 4$ \\
\hline$\left[\mathrm{WCl}_{4}\left(\mathrm{O}-\mathrm{C}_{6} \mathrm{H}_{3} \mathrm{Me}_{2}\right)_{2}\right]$ & 0 & $4 \pm 2$ & $50 \pm 4$ & $12 \pm 4$ & 0 & $4 \pm 2$ \\
\hline
\end{tabular}

The by-products contain mainly dodecene, a product of hexene dimerization.

The reactions were performed at least three times. 
Table 3. Conversion of methyl-10-undecenoate, using $\left[\mathrm{WCl}_{6}\right]$ and [WCl $\left(\mathrm{W}_{4}-\mathrm{C}_{6} \mathrm{H}_{3} \mathrm{Cl}_{2}\right)_{2}$ ] as catalysts and $\mathrm{Ph}_{2} \mathrm{SiH}_{2}$, PMHS and $\mathrm{SnMe}_{4}$ as cocatalysts. Reaction time: $5 \mathrm{~h}$. Temperature: $348 \mathrm{~K}$.

\begin{tabular}{lll}
\hline & {$\left[\mathrm{WCl}_{\mathbf{6}}\right](\boldsymbol{\%})^{\mathbf{1 2}}$} & {$\left[\mathrm{WCl}_{\mathbf{4}}\left(\mathbf{O}-\mathrm{C}_{\mathbf{6}} \mathbf{H}_{\mathbf{3}} \mathbf{C l}_{2}\right)_{2}\right](\boldsymbol{\%})$} \\
$\mathrm{Ph}_{2} \mathrm{SiH}_{2}$ & 70 & 60 \\
$\mathrm{PMHS}$ & 64 & 72 \\
$\mathrm{SnMe}_{4}$ & 59 & 55 \\
\hline
\end{tabular}

The reactions were performed at least three times.

inert conditions such as glove box handling, which is necessary when handling tungstenhexachloride..$^{12,20}$

To summarize, the silicon compounds $\mathrm{Ph}_{2} \mathrm{SiH}_{2}$ and PMHS were used as cocatalysts with tungsten phenoxides in the metathesis of a non-functionalized and a functionalized olefin. The results showed activities and selectivities comparable to those obtained by using the known $\left[\mathrm{WCl}_{6}\right]-\mathrm{SnMe}_{4}$-based system. Furthermore, [WCl ${ }_{4}(\mathrm{OAr})_{2}$ ] plus PMHS or $\mathrm{Ph}_{2} \mathrm{SiH}_{2}$ is applicable with both non-functionalized and functionalized olefins. On the other hand, the $\left[\mathrm{WCl}_{6}\right] /$ silicon compounds, as demonstrated in a previous study, ${ }^{13}$ provided good results when an ester was used as an olefin, although the addition of phenol promoters was necessary with 1-hexene.

\section{Conclusions}

The systems based on the $\left[\mathrm{WCl}_{4}(\mathrm{OAr})_{2}\right]$-silicon compound proved to be active and selective for the metathesis reaction of 1-hexene, particularly when the structure of the aryloxide ligands contains electronegative groups. Of all the cocatalysts studied, polymethylhydrosiloxane (PMHS) proved to be very active and selective, even with [ $\left.\mathrm{WCl}_{4}\left(\mathrm{C}_{6} \mathrm{H}_{3} \mathrm{Me}_{2}\right)_{2}\right]$, which displayed little activity with other cocatalysts. PMHS was the best cocatalyst for both 1-hexene and methyl-10-undecenoate metathesis. It should be noted that this compound is nontoxic, non-volatile, easy to handle and inexpensive, rendering it a good alternative for such reactions.

\section{Acknowledgements}

The authors are indebted to CNPq, CAPES and FAPERGS for the financial support of this work.

\section{References}

1. Ivin, K.J.; Mol, J.C. In Olefin Metathesis and Metathesis Polymerization; Academic Press: New York, 1997.

2. Streck, R.; J. Mol. Catal, 1992, 76, 359.

3. Grubbs, R.H.; Miller, S.J.; Fu, G.; Acc. Chem. Res. 1995, 28, 446.

4. Schrock, R.R.; Depue, R.T.; Feldman, J.; Schaverien, C.J.; Dewan, J.C.; Liu, A.H.; J. Am. Chem. Soc. 1988, 110, 1423.

5. Fu, G.C.; Nguyen, S.T.; Grubbs, R.H.; J. Am. Chem. Soc. 1993, 115, 9856.

6. Weskamp, T.; Schattenmann, W.C.; Spiegler, M.; Herrmann, W.A.; Angew. Chem. Int. Ed. 1998, 37, 2490.

7. Furstner, A.; Picquet, M.; Bruneau, C.; Dixneuf, P.H.; Chem. Commun. 1998, 1315.

8. Mol, J.C.; J. Mol. Catal. 1994, 90, 185.

9. Lefèbvre, F.; Leconte, M.; Pagano, S.; Mutch, A.; Basset, J.M.; Polyhedron, 1995, 14, 3209; Schrock, R.R.; Polyhedron, 1995, 143177.

10. Dodd, H.T.; Rutt, K.J.; J. Mol. Catal. 1985, 28, 33.

11. Quignard, F.; Leconte, M., Basset, J.M.; J. Mol. Catal. 1985, 28, 27; Quignard, F.; Leconte, M., Basset, J.M.; J. Mol. Catal. 1986, 36, 13.

12. Baibich, I.M.; Gregório, J.R.; Kern, C.; Rudler, H.; J. Braz. Chem. Soc. 1996, 6, 313.

13. Baibich, I.M.; dos Santos, J.H.Z.; Kern, C.; J. Mol. Catal. 1998, 136, 213.

14. Randall, M.L.; Snapper, M.L.; The Strem Chemiker, 1998, 12, 1.

15. Mol, J.C.; J. Mol. Catal. 1994, 90, 185.

16. Quignard, F.; Leconte, M.; Basset, J.M.; Hsu, L.Y.; Alexander, J.J.; Shore, S.G.; Inorg. Chem. 1987, 26, 4272.

17. Piatinicki, C.M.S.; Azambuja, D; Baibich, I.M.; Kern, C.; Selbach, V.M.; Abstracts of the $43^{\text {rd }}$ International Conference on Analytical Sciences and Spectroscopy, Montreal, Canada, 1997.

18. Lipowitz, J.; Bowman, S.A.; J. Org. Chem. 1973, 38, 162.

19. Vosloo, H.C.M.; Dickinson, A.J.; du Plessis, J.A.K.; J. Mol. Catal. A, 1997, 115, 199.

20. Mocella, M.T.; Busch, M.A.; Muetterties, E.L.; J. Am. Chem. Soc. 1976, 98, 1283

Received: October 26, 2000

Published on the web: October 11, 2001

FAPESP helped in meeting the publication costs of this article. 